\title{
Arthritis-induced increase in serum levels of IGF-binding protein-3 in rats is secondary to the decrease in its proteolytic activity
}

\author{
I Ibáñez de Cáceres, J M P Holly ${ }^{1}$, T Priego, A I Martín ${ }^{2}$, \\ A López-Calderón and $\mathbf{M}$ A Villanúa \\ Department of Physiology, Faculty of Medicine, Complutense University, 28040 Madrid, Spain \\ ${ }^{1}$ University Department of Medicine, Division of Surgery, University of Bristol, Bristol BS2 8HW, UK \\ ${ }^{2}$ Department of Morphology and Physiology, Europea University, 28670 Madrid, Spain \\ (Requests for offprints should be addressed to M A Villanúa; Email: anvi@med.ucm.es)
}

\begin{abstract}
Adjuvant-induced arthritis is a chronic inflammatory illness that induces a catabolic state, with a decrease in pituitary GH and hepatic IGF-I synthesis. We have previously observed an increase in serum IGF-binding protein-3 (IGFBP-3) in arthritic rats, and found that GH administration prevents the increase in circulating IGFBP-3 in arthritic rats. The aim of this work was therefore to study IGFBP-3 synthesis in the liver as well as its proteolysis in serum as the two possible causes of the increased circulating IGFBP-3 in arthritic rats. The effect of recombinant human $\mathrm{GH}$ (rhGH) administration was also analysed. Adult male Wistar rats were injected with complete Freund's adjuvant or vehicle, and 14 days later they were injected s.c. daily until day 22 after adjuvant injection with $\mathrm{rhGH}(3 \mathrm{IU} / \mathrm{kg})$ or saline. Three hours after the last GH injection, all rats were killed by decapitation. Arthritis increased serum IGFBP-3 levels $(P<0 \cdot 01)$. The increase in serum IGFBP-3 levels in arthritic rats seems to
\end{abstract}

be due to decreased proteolysis $(P<0 \cdot 01)$ rather than to an increased synthesis, since liver IGFBP-3 mRNA content was not modified by arthritis. GH administration to control rats resulted in an increase in both hepatic IGFBP-3 mRNA content and in serum IGFBP-3 levels in spite of the increase in IGFBP-3 proteolysis in serum. In arthritic rats, GH treatment did not modify liver IGFBP-3 synthesis, but it increased serum proteolysis of IGFBP-3, leading to a serum concentration of IGFBP-3 similar to that of control rats. Furthermore, there was a negative correlation between circulating IGFBP-3 and its proteolytic activity in the serum of adjuvant-induced arthritic rats. These data suggest that in chronic arthritis the increase in IGFBP-3 serum concentration is secondary to a decrease in proteolytic activity, rather than to an increase in hepatic IGFBP-3 gene expression.

Journal of Endocrinology (2002) 173, 357-364

\section{Introduction}

Rat adjuvant-induced arthritis (AIA) is a well-established model of rheumatoid arthritis (RA) (Langman et al. 1990, Wooley 1991). Histologic changes, including leukocyte invasion and synovial cell activation, precede clinical symptoms such as joint swelling and weight loss (LópezBote et al. 1988, Halloran et al. 1996). The decrease in body weight in AIA induces a catabolic state (Roubenoff et al. 1997) that may result, at least in part, from a lack of anabolic hormones such as insulin-like growth factor-I (IGF-I) and growth hormone (GH). A decrease in serum GH and pituitary GH mRNA has been described during the early phase before and after the disease develops (Neidhart \& Flückiger 1992, Selgas et al. 1997). We have reported that the decrease in GH mRNA is concomitant with a decrease in serum and hepatic IGF-I, which correlates with the decrease in body weight in AIA (López-Calderón et al. 1999).

The bioactivity of IGF-I is regulated by IGF-I binding proteins (IGFBPs), where IGFBP-3 is the main carrier of circulating IGF-I and, together with the acid-labile subunit (ALS), it forms a high molecular weight ternary complex. The ternary complex is thought to increase the half-life of circulating IGF-I and to control the access of IGF-I to extravascular target tissues (Binoux \& Hossenlopp 1988, Martin \& Baxter 1992). IGFBP-3 also plays an important role in the cellular environment, where it may both inhibit and potentiate IGF-I-stimulated DNA synthesis (De Mellow \& Baxter 1988, Conover 1992). IGFBP-3, as well as IGF-I and ALS, are regulated by GH. Thus, IGFBP-3 levels are decreased in GH deficiency and increased in acromegaly (Baxter \& Martin 1986, Blum et al. 1990). Moreover, in GH-deficient dwarf rats and 
hypophysectomized rats, GH induces IGFBP-3 and restores the $150 \mathrm{kDa}$ ternary complex (Gargosky et al. 1994, Fielder et al. 1996). However, we have observed during chronic inflammation that the decrease in $\mathrm{GH}$ secretion and in circulating IGF-I levels is associated with high levels of IGFBP-3 in rat serum (Soto et al. 1998, López-Calderón et al. 1999). Furthermore, an increase in plasma IGFBP-3 has also been recently reported in RA patients (Neidel 2001).

The mechanisms by which IGFBP-3 activity can be regulated is through its hepatic synthesis, since the liver has relatively high levels of IGFBP-3 mRNA (Albiston \& Herington 1992) or through its proteolysis. This last modulation of IGFBP-3 occurs during pregnancy in humans (Giudice et al. 1990, Hossenlopp et al. 1990), rats (Davenport et al. 1990) and mice (Fielder et al. 1990). The generated fragments bind IGF with lower affinity compared with intact IGFBP-3, resulting in an increased bioavailability of IGF (Blat et al. 1994). Increased proteolysis of IGFBP-3 has also been observed under conditions of physiological stress including post-surgery (Frost et al. 1993), diabetes (Bang et al. 1994) and cancer (Frost et al. 1993).

We have previously observed an increase in serum IGFBP-3 in arthritic rats, and found that GH administration prevents this increase (Ibáñez de Cáceres et al. 2000). Therefore, the aim of this work was to study the mechanism responsible for the increase in serum IGFBP-3 in arthritic rats, by evaluating hepatic synthesis and proteolysis of IGFBP-3 in the serum. The effect of recombinant human $\mathrm{GH}(\mathrm{rhGH})$ administration was also analysed.

\section{Materials and Methods}

\section{Animals}

Male Wistar rats were housed three or four per cage with free access to food and water, under constant conditions of temperature $\left(20-22^{\circ} \mathrm{C}\right)$ and light (lights on from 0730 to $1630 \mathrm{~h}$ ). The procedures followed the guidelines recommended by the European Union for the care and use of laboratory animals. Control and arthritic rats were purchased from Charles River (Barcelona, Spain). Arthritis was induced by an intradermal injection of a suspension of $1 \mathrm{mg}$ heat-killed Mycobacterium butyricum in incomplete Freund's adjuvant into the tail base. Control animals were injected with vehicle (paraffin oil). Fourteen days after adjuvant injection, control and arthritic animals were divided into two groups, one injected daily with $3 \mathrm{IU} / \mathrm{kg}$ rhGH s.c. (Saizen, Serono, Italy) and the other group received $250 \mu \mathrm{l}$ saline, until day 22 after adjuvant injection. Assessment of arthritis was performed by measuring the arthritis index of each animal, which was scored by grading each paw from 0 to 4 . Grading was determined as: 0 , no erythema or swelling; 1 , slight erythema or swelling of one or more digits; 2, swelling of the entire paw; 3, erythema and swelling of the ankle; 4, ankylosis, incapacity to bend the ankle. The severity score was the sum of the clinical scores of each limb, the maximum value being 16. Rats with a severity score below 6 were excluded from the study (two rats of 20 injected with adjuvant). Arthritis score was $12.5 \pm 0.6$ (means \pm S.E.M.) on day 22 in arthritic rats injected with saline. On day 22 , all rats were killed by decapitation, $2.5 \mathrm{~h}$ after the last $\mathrm{rhGH}$ or saline injection. Trunk blood was allowed to clot, centrifuged and serum stored at $-20{ }^{\circ} \mathrm{C}$ until IGF-I, IGFBP-3 and proteolysis were measured. The liver was removed, dissected, frozen in liquid nitrogen and stored at $-80{ }^{\circ} \mathrm{C}$ until RNA extraction was performed.

\section{IGF-I determination by radioimmunoassay (RIA)}

Total IGF-I concentrations were measured by a doubleantibody RIA (Soto el al. 1998) using the antibody NIDDK UB2-495 distributed by the Hormone Distribution Program of NIDDK through the National Hormone and Pituitary Program, a gift from Dr Underwood and Dr Van Wik. Serum IGFBPs were removed by acid-ethanol extraction. Levels of IGF-I were expressed in terms of IGF-I A52-EPD-186 standard (Eli Lilly \& Company, Madrid, Spain). The intra-assay coefficient of variation was $8 \%$, all samples were run in the same assay.

\section{Western ligand blot}

Western blots were prepared as previously described (Hossenlopp et al. 1986). Two microlitres of sera were diluted in sample buffer and boiled for $2 \mathrm{~min}$ at $100{ }^{\circ} \mathrm{C}$, loaded onto $1 \%$ SDS- $12.5 \%$ polyacrylamide gels, and electrophoresed under non-reducing conditions. Proteins were transferred onto nitrocellulose sheets (Hybond-C extra; Amersham International plc, Amersham, Bucks, UK). The membranes were dried and blocked for $1 \mathrm{~h}$ with $5 \%$ non-fat dry milk, $0 \cdot 1 \%$ Tween (Sigma, St Louis, MO, USA), in Tris-buffered saline. Membranes were probed overnight at $4{ }^{\circ} \mathrm{C}$ with ${ }^{125}$ I-labelled IGF-I $\left(5 \times 10^{5}\right.$ c.p.m. $/ \mathrm{ml}$ ). The nitrocellulose sheets were then washed, dried and exposed at $-80{ }^{\circ} \mathrm{C}$ to $\mathrm{X}$-ray film (Kodak X-Omat AR; Eastman Kodak, Rochester, NY, USA) and to two intensifying screens for 1-4 days according to the signal obtained. The signals of the film were quantified by densitometry using a PC-Image VGA24 program for Windows. The density of the IGFBP bands in each lane was expressed as the percentage of the mean density of sera from control rats injected with saline.

\section{Assay for IGFBP-3 proteolytic activity}

Sera samples were assayed for their ability to fragment radiolabelled IGFBP-3 as described by Lamson et al. (1991). Serum samples $(5 \mu \mathrm{l})$ were mixed with 15000 
c.p.m. ${ }^{125}$ I-ngIGFBP-3 (recombinant human nonglycosylated IGFBP-3 (rhIGFBP-3), Diagnostic System Laboratories, Webster, Texas, USA, iodinated using the chloramine T method) in a total volume of $30 \mu$ in $0.05 \mathrm{M}$ phosphate buffer, $\mathrm{pH} 7 \cdot 4$. The mixture was incubated for $18 \mathrm{~h}$ at $37^{\circ} \mathrm{C}$ and the reaction was stopped by boiling the mixture with $7 \mu \mathrm{l} 5 \times$ SDS loading buffer before loading onto a $12.5 \%$ SDS-polyacrylamide gel and run overnight. Gels were fixed and dried (Bio-Rad gel drying system-543, Madrid, Spain) and exposed to X-ray film at $-80{ }^{\circ} \mathrm{C}$ for $2-3$ days. Proteolysis was measured by densitometry of intact IGFBP-3 remaining in each lane and expressed as a percentage of control rat intact IGFBP-3.

\section{Northern blot analysis of hepatic IGFBP-3 $m R N A$}

Total liver RNA was extracted by the guanidine thiocyanate method using a commercial reagent (Ultraspec RNA; Biotecx Laboratories, Houston, TX, USA). The extracted RNA was dissolved in diethylpyrocarbonate water, $0 \cdot 1 \%$ SDS and quantified at $260 \mathrm{~nm}$; RNA integrity was confirmed by agarose gel electrophoresis. For Northern blotting, $20 \mu \mathrm{g}$ denatured RNA from each liver were separated by formaldehyde-agarose gel electrophoresis, transferred to nylon membranes (Hybond-N+; Amersham International plc) and fixed by u.v. crosslinking (Fotodyne, Hartland, WI, USA). The rat IGFBP-3 probe corresponded to nucleotides of rat cDNA described by Albiston and Herington (1990). The ${ }^{32}$ P-labelled RNA antisense probe was generated from linearized PEGEM $4 Z$ plasmid with $\left[a^{32} \mathrm{P}\right]$ cytidine triphosphate (Nuclear Ibérica, Madrid, Spain) and T7 RNA polymerase (Roche Molecular Biochemicals, Barcelona, Spain). Prehybridization was performed for $30 \mathrm{~min}$ at $68^{\circ} \mathrm{C}$ in ULTRAhyb buffer (Ambion, Austin, TX, USA) followed by hybridization for $16 \mathrm{~h}$ at the same temperature with $5 \times 10^{6}$ c.p.m./ml IGFBP-3 labelled riboprobe, in the same buffer. The membranes were washed twice with $2 \times$ SSC, $0 \cdot 1 \%$ SDS at $68^{\circ} \mathrm{C}$ for $10 \mathrm{~min}$, and twice with $0 \cdot 1 \times \mathrm{SSC}$, $0 \cdot 1 \% \operatorname{SDS}$ at $68^{\circ} \mathrm{C}$ also for $10 \mathrm{~min}$. To verify loading, control hybridization was performed with a 28S DNA probe labelled with ${ }^{32} \mathrm{P}-\mathrm{dCTP}$ by random primer (Roche). The membranes were exposed at $-80^{\circ} \mathrm{C}$ for 2-7 days. The intensities of autoradiograph signal levels were measured and expressed as the percentage of the mean intensity of the control group injected with saline.

\section{Statistical analysis}

Statistics were computed using the statistics program STATGRAPHICS plus for Windows. Data are presented as means \pm S.E.M. and were analysed by two-way ANOVA followed by Duncan's multiple range test. Correlation between two variables was calculated by linear regression. Statistical significance was set at $P<0 \cdot 05$.
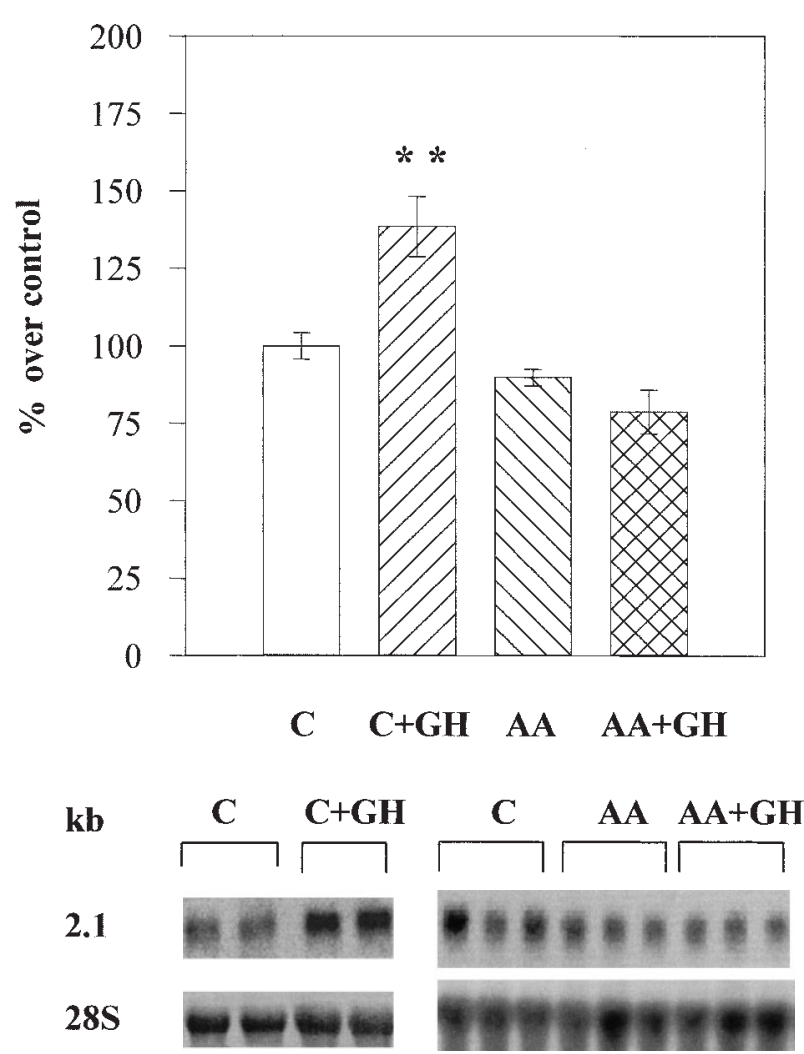

Figure 1 Effect of AIA and rhGH administration on liver IGFBP-3 mRNA content. A representative Northern blot of IGFBP-3 mRNA hybridization is shown in the lower panel. RNA was hybridized with an RNA probe for rat IGFBP-3 mRNA as described in Materials and Methods. The size of the hybridization band (in kilobases) and the ribosomal 28S RNA are indicated on the left; each band corresponds to an individual animal from the group indicated. $\mathrm{C}=$ control rats injected with saline, $\mathrm{C}+\mathrm{GH}=$ control rats injected with $\mathrm{rhGH}, \mathrm{AA}=$ arthritic rats injected with saline,

$\mathrm{AA}+\mathrm{GH}=$ arthritic rats injected with rhGH. Quantitative analyses are expressed as percentages of control rats injected with saline (upper panel). Each bar represents the mean \pm S.E.M. for five rats. ${ }^{*} P<0 \cdot 01$ vs control group injected with saline (ANOVA+ Duncan's multiple comparison test).

\section{Results}

Arthritis induced a dramatic decrease in body weight gain $(15 \cdot 4 \pm 2 \cdot 2 \mathrm{~g} / 7$ days vs $61 \pm 1 \cdot 7$, means \pm S.E.M., $P<0 \cdot 01)$, and $\mathrm{GH}$ administration increased body weight gain in arthritic rats $(25 \cdot 3 \pm 2.5 \mathrm{~g} / 7$ days, $P<0 \cdot 01)$, but not in control rats. Arthritis induced a significant decrease in serum concentrations of IGF-I $(1113 \pm 59 \mathrm{ng} / \mathrm{ml}$ vs $1373 \pm 65, \quad P<0 \cdot 05)$, and $\mathrm{GH}$ administration did not modify circulating IGF-I in control or arthritic rats. Similarly, GH treatment did not modify the arthritis index scores (data not shown).

The IGFBP-3 mRNA content in the liver is represented in Fig. 1: arthritis did not modify IGFBP-3 gene expression in the liver. $\mathrm{GH}$ administration increased the 


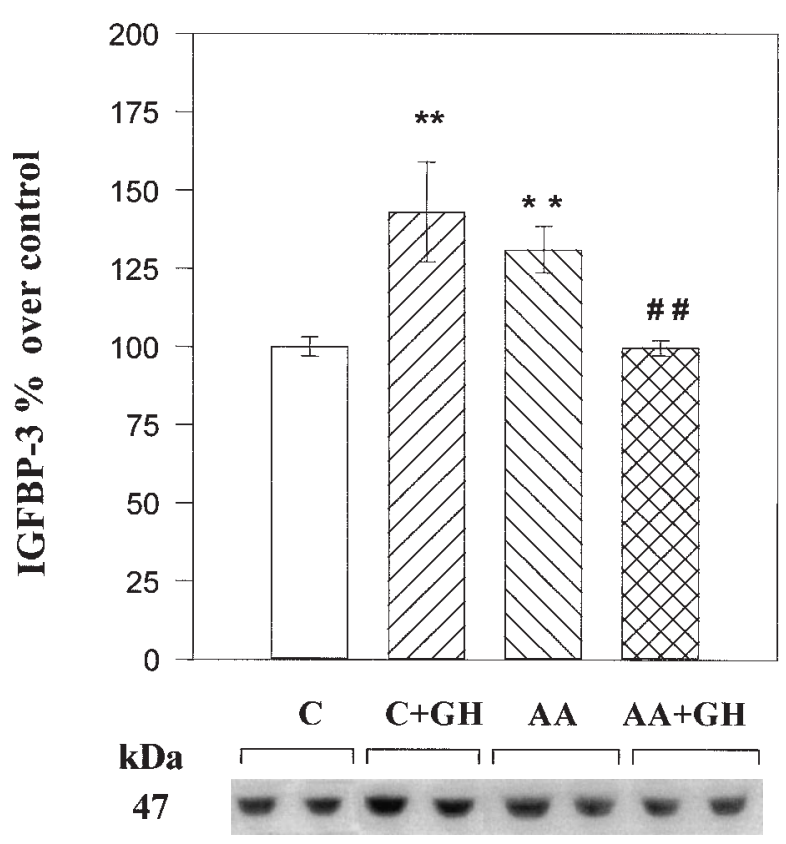

Figure 2 Effect of rhGH administration to control and arthritic rats on the serum IGF-I-binding activity of IGFBP-3. A representative Western ligand blot of IGFBP-3 in $2.5 \mu \mathrm{l}$ pool serum from the different groups is shown at the bottom. IGFBPs were separated by a $12.5 \%$ SDS-PAGE gel, transferred to nitrocellulose, ligand blotted with ${ }^{125}$ I-IGF-I, and visualized via autoradiography, the approximate molecular weight of the band is indicated on the left. $\mathrm{C}=$ control rats injected with saline, $\mathrm{C}+\mathrm{GH}=$ control rats injected with $\mathrm{rhGH}, \mathrm{AA}=$ arthritic rats injected with saline,

$\mathrm{AA}+\mathrm{GH}=$ arthritic rats injected with $\mathrm{rhGH}$. Data (means \pm S.E.M.) from at least five individual rats were quantified by densitometry and expressed as a percentage of the mean value of control rats treated with saline. ${ }^{* *} P<0 \cdot 01$ vs control group injected with saline, ${ }^{\# \# P} P<0 \cdot 01$ vs arthritic rats injected with saline (Duncan's multiple comparison test).

IGFBP-3 mRNA content in the liver in control rats $(P<0 \cdot 01)$, but not in arthritic rats.

As shown in Fig. 2, the IGF-I-binding activity of IGFBP-3 in serum was increased in arthritic rats $(P<0 \cdot 01)$. $\mathrm{GH}$ administration had different effects: it increased the IGF-I-binding activity of IGFBP-3 in the serum of control animals, but $\mathrm{GH}$ administration decreased this binding activity $(P<0 \cdot 01)$ in arthritic rats.

The IGFBP-3 proteolytic activity in rat serum was different from that observed in humans (Fig. 3). In normal human serum, the $29 \mathrm{kDa}$ band corresponding to the added intact IGFBP-3 was more intense than that in normal rat serum, suggesting that IGFBP-3 proteolysis activity was less active in normal human serum than in normal rat serum. The IGFBP-3 fragments corresponding to 21.5 and $17 \mathrm{kDa}$ bands were increased and the intact IGFBP-3 band was decreased in pregnant human serum as a result of increased IGFBP-3 proteolysis. In pregnant rat serum, the proteolytic activity was also increased in comparison with normal rat serum. However, in normal

\section{Human Rat}

kDa

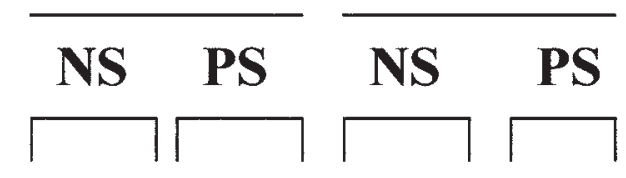

29

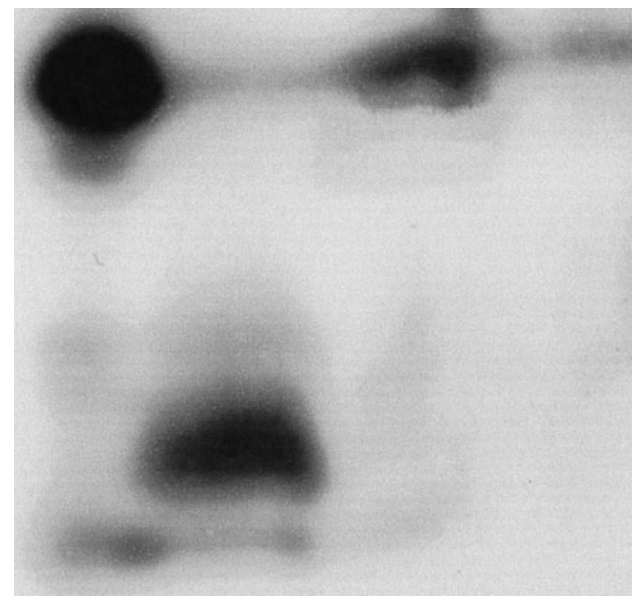

Figure 3 Incubation of ${ }^{125}$ I-rhIGFBP-3 with normal (NS) or pregnant (PS) serum from rats or humans. Serum was incubated for $18 \mathrm{~h}$ at $37^{\circ} \mathrm{C}$ with 15000 c.p.m. $\left({ }^{125} \mathrm{I}\right.$-rhlGFBP-3) in $30 \mu \mathrm{l}$, and was submitted to analysis by SDS-PAGE. Molecular weights are shown on the left. Intact ${ }^{125}$ I-rhIGFBP-3 appears as a $29 \mathrm{kDa}$ band, bands of 21.5 and $17 \mathrm{kDa}$ were generated in both human sera as a result of ${ }^{125} \mathrm{I}$-rhlGFBP-3 fragmentation.

and pregnant rat serum, the higher IGFBP-3 proteolysis was not associated with an increase in the 21.5 and $17 \mathrm{kDa}$ bands, suggesting different protease activities in both species. The proteolysis in rat serum presumably results in more extensive fragmentation generating smaller fragments, which then run off the bottom of the gel.

Proteolysis was decreased in arthritic rats $(P<0 \cdot 01)$, reaching values almost similar to normal human serum (Fig. 4), GH treatment had the opposite effect, since it increased the proteolytic activity in serum in both control and arthritic rats $(P<0 \cdot 01)$. In control rats injected with saline and in both groups of arthritic rats, there was a negative correlation between the IGFBP-3 proteolytic activity in serum and the serum concentration of IGFBP-3 $\left(r=0 \cdot 58, \mathrm{~F}_{1,15}=7,6, P<0 \cdot 05\right)$. The rats that had the lowest serum concentration of IGFBP-3 had the highest IGFBP-3 proteolytic activity in serum. However, in the control rats treated with $\mathrm{GH}$ there was no correlation between IGFBP-3 in serum and its proteolysis (Figs 2 and 4).

\section{Discussion}

In this study we have analyzed the proteolytic activity for circulating IGFBP-3 and its hepatic synthesis in arthritic 

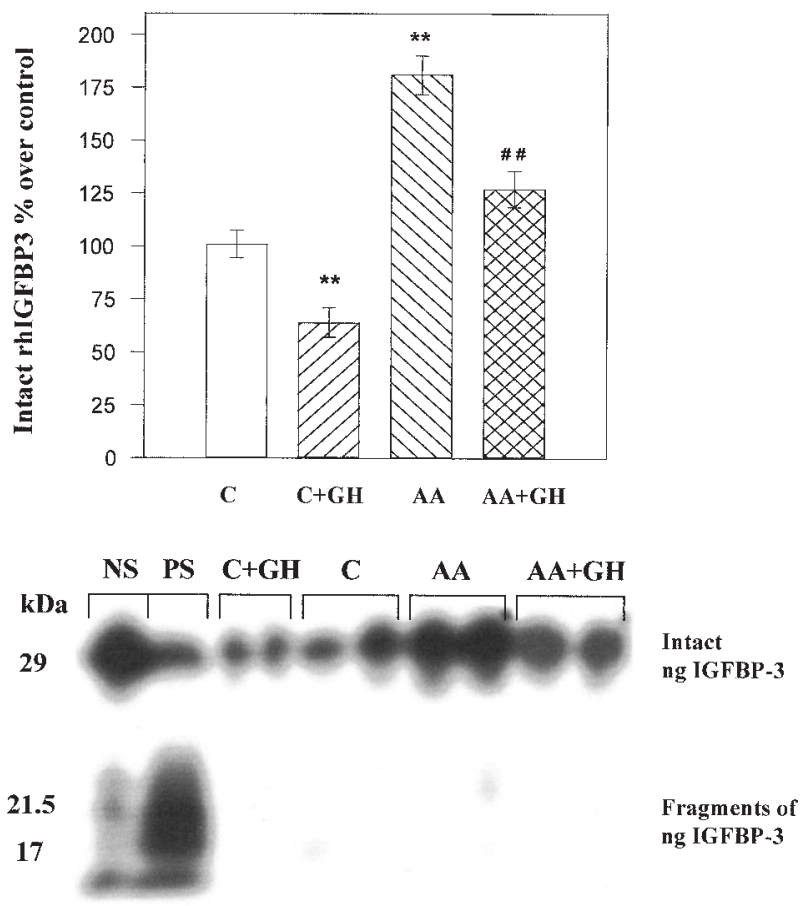

Figure 4 IGFBP-3 proteolytic activity in the serum of control or arthritic rats treated with saline or rhGH for 8 days. ${ }^{125}$ I-rhlGFBP-3 was incubated for $18 \mathrm{~h}$ at $37^{\circ} \mathrm{C}$ with sera and submitted to SDS-PAGE as described in Materials and Methods. A representative autoradiograph of IGFBP-3 protease assay of rat serum samples from the different groups, from normal human serum (NS), and serum from pregnant women (PS) are shown in the lower panel. $\mathrm{C}=$ control rats injected with saline,

$\mathrm{C}+\mathrm{GH}=$ control rats injected with $\mathrm{rhGH}, \mathrm{AA}=$ arthritic rats injected with saline, $\mathrm{AA}+\mathrm{GH}=$ arthritic rats injected with rhGH. Approximate sizes of fractions from NS and PS are indicated on the left of the panel. After quantifying the intact ${ }^{125}$ I-rhIGFBP-3 band from individual rats by densitometry, IGFBP-3 proteolysis was expressed as a percentage of the mean of the sera from the control rats injected with saline (upper panel). Each point represents the mean \pm S.E.M. for at least seven rats per group.

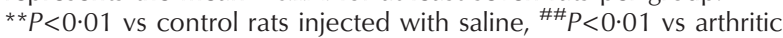
rats injected with saline (Duncan's multiple range test).

rats as the two possible causes of the increase in serum IGFBP-3. The results showed that the high serum levels of IGFBP-3 in arthritic rats appear to be largely due to decreased proteolysis of IGFBP-3, since hepatic synthesis of IGFBP-3 was not changed.

As we have already described in arthritic rats (Ibáñez de Cáceres et al. 2000), concentrations of IGFBP-3 in serum are increased and GH treatment prevents this increase. These changes in serum protein concentrations did not correlate with the hepatic synthesis of IGFBP-3, since liver IGFBP-3 mRNA content was not modified by arthritis and the synthesis remained constant in response to GH. Similarly, liver IGFBP-3 mRNA in humans was not changed after GH treatment (Olivecrona et al. 1999). The results of the present study contrast with several studies that indicate the GH dependency of circulating IGFBP-3 in humans (Baxter \& Martin 1986, Blum et al. 1990, Olivecrona et al. 1999) and rats (Gargosky et al. 1994, Fielder et al. 1996, Lemmey et al. 1997), and its hepatic synthesis in the rat (Lemmey et al. 1997). However, we found this GH dependency of IGFBP-3 synthesis in control rats in which $\mathrm{GH}$ treatment increased hepatic IGFBP-3 mRNA content and serum concentrations of IGFBP-3.

It is not clear whether $\mathrm{GH}$ acts directly in stimulating IGFBP-3 synthesis or is mediated by IGF-I produced in the hepatocytes under GH control (Villafuerte et al. 1994). Scharf et al. (1996) reported that IGF-I is a potent stimulator for the synthesis of IGFBP-3 and ALS, in co-cultures of Kupffer cells and hepatocytes in adult rats, and that GH did not exert direct effects on IGFBP-3 synthesis, but stimulated the expression of ALS. In adult female rats, serum IGFBP-3 as well as hepatic IGFBP-3 mRNA levels increased after IGF-I treatment (van Neck et al. 2000). In contrast, IGF-I mRNA levels and IGFBP-3 mRNA in the liver were reduced in hypophysectomized rats, and GH treatment increased both of them (Domene et al. 1993). However, in GH-deficient dwarf rats, it has been reported (Lemmey et al. 1997) that GH treatment increased liver IGFBP-3 mRNA levels, whereas IGF-I had no effect, which implies that GH might have a direct function in the regulation of IGFBP-3 synthesis.

In control rats, $\mathrm{GH}$ treatment increases the hepatic IGF-I synthesis (López-Calderón et al. 2001), which correlates with the increase in IGFBP-3 mRNA, suggesting a GH-IGF-I dependency of IGFBP-3 synthesis. However, we previously found a decrease in hepatic IGF-I gene expression in arthritic rats (López-Calderón et al. 2001) and IGFBP-3 mRNA levels in the liver were unchanged. Moreover, GH treatment in arthritic rats resulted in an increase in hepatic IGF-I synthesis that was not accompanied by an increase in IGFBP-3 synthesis. The results from the arthritic rats suggest that rat liver biosynthesis of IGFBP-3 is not only dependent on the GH-IGF-I system, but that other mechanisms can also be involved.

In patients with RA, IGFBP-3 was elevated in plasma and synovial fluid compared with osteoarthritis, while IGF-I did not differ significantly between the two groups (Neidel et al. 1997). However, some authors found increased IGFBP-3 in synovial fluid of RA patients (Fernihough et al. 1996), while serum IGFBP-3 levels were decreased (Fernihough et al. 1996, Lemmey et al. 2001). The discrepancies between these authors could be due to the degree of disease activity, to the pharmacological treatment or to the degree of serum IGFBP-3 proteolysis. Some of these authors measured IGFBP-3 proteolysis in synovial fluid of patients with RA, as discussed below. But none of them measured IGFBP-3 proteolysis in serum, probably because in normal human serum 
IGFBP-3 proteolysis is negligible as can be observed in Fig. 3 of this study and which has also been observed by other authors (Whellams et al. 2000). In addition, in RA patients, the synovial fluid concentrations of IGFBP-3 were positively correlated with synovial fluid levels of interleukin- $1 \beta$ and tumour necrosis factor- $\alpha$ (Neidel et al. 1997). Also, Fernihough et al. (1996) found a significant correlation between levels of IGFBP-3 in the synovial fluid and serum levels of C-reactive protein in RA patients. These data indicate that inflammatory products could induce IGFBP-3 gene expression and release from other tissues, such as endothelial cells, which could mediate the changes in serum concentrations of IGFBP-3 in arthritic rats.

The proteolysis of IGFBP-3 was decreased in the serum of arthritic rats, which correlates with the observed increase in serum concentrations of this protein. Similarly, in the synovial fluid of patients with RA, the proteolysis of IGFBP-3 was decreased (Fernihough et al. 1996, Whellams et al. 2000) and the levels of IGFBP-3 were increased (Fernihough et al. 1996, Tavera et al. 1996, Whellams et al. 2000). Inverse correlation between plasma IGFBP-3 levels and proteolysis of IGFBP-3 has also been found in patients after surgery, but show a reduction in circulating IGFBP-3 as a result of IGFBP-3-specific proteases (Davenport et al. 1992). Although a variety of catabolic states has been characterized by the presence of increased IGFBP-3 proteolysis (Davenport et al. 1992, Cotterill et al. 1996), this does not always occur, as we have observed in arthritic rats and humans. Also, in patients with anorexia nervosa, another catabolic condition, the IGFBP-3 proteolytic activity was not increased, but decreased levels of circulating IGF-I and IGFBP-3 were found (Støving et al. 1999).

During inflammation, data in vivo and in vitro suggest that neutrophil proteases, cathepsin G and elastase, may potentially act as IGFBP proteases (Gibson \& Cohen 1999). These proteases do not seem to play a major role in AIA, since we found decreased IGFBP-3 proteolysis despite an increase in the percentage of neutrophils in blood and synovial tissue (Szekanecz et al. 2000).

Our results support the GH dependency of IGFBP-3 proteolysis, since proteolysis of IGFBP-3 was decreased in arthritic rats, and we found an increased proteolytic activity of IGFBP-3 in serum in both control and arthritic rats after GH treatment. Data in the literature about the GH dependency of proteolytic activity towards IGFBP-3 are unclear. After major surgery in humans the degree of IGFBP-3 proteolysis is not influenced by GH administration (Skjaerbaek et al. 1998a). Also, GH therapy administered to $\mathrm{GH}$-deficient patients and somatostatin administration to acromegalic patients had no effect on IGFBP-3 proteolytic activity (Skjaerbaek et al. 1998b, Lassarre et al. 2001). This suggests that GH is probably not the major direct regulator of the proteolysis of IGFBP-3. This independence of the GH-IGF-I axis has also been suggested in GH-deficient patients including pediatric cases (Yamada et al. 1999), in Laron syndrome (Vaccarello et al. 1993) and in patients with diabetes mellitus (Cheetham et al. 1998). However, in experimental animals such as dwarf mice or hypophysectomized rats, a strong proteolytic activity has been reported (Koedam et al. 1998). In contrast, Rutishauser et al. (1993) described the fact that serum from normal rats contains a proteolytic activity against IGFBP-3 which disappears after hypophysectomy and reappears after infusion of GH. Similarly, we found an increase in IGFBP-3 proteolysis in arthritic rats after $\mathrm{GH}$ administration.

Furthermore, the results of Rutishauser et al. (1993) suggest that the proteolytic activity for IGFBP-3 is specifically dependent on $\mathrm{GH}$, but by a different mechanism than through the induction of IGF-I, because administration of IGF-I had no effect on the IGFBP-3 proteolytic activity in the hypophysectomized rat. Accordingly, in patients with Laron dwarfism characterized by GH insensitivity and very low levels of IGF-I (Laron et al. 1980), an increased serum IGFBP-3 proteolytic activity has been described (Cotterill et al. 1992, Fielder et al. 1992).

\section{Acknowledgements}

The authors are indebted to A Carmona for technical assistance and to Christina Bickart for correction of the manuscript. This study was supported by grant from FIS (00/0949) and by a fellowship to I IdeC (BEFI, 99/9020).

\section{References}

Albiston AL \& Herington AC 1990 Cloning and characterization of the growth hormone-dependent insulin-like growth factor binding protein (IGFBP-3) in the rat. Biochemical and Biophysical Research Communications 166 892-897.

Albiston AL \& Herington AC 1992 Tissue distribution and regulation of insulin-like growth factor (IGF)-binding protein-3 messenger ribonucleic acid (mRNA) in the rat: comparison with IGF-I mRNA expression. Endocrinology 130 497-502.

Bang P, Brismar K \& Rosenfeld RG 1994 Increased proteolysis of insulin-like growth factor-binding protein-3 (IGFBP-3) in noninsulin-dependent diabetes mellitus serum, with elevation of a 29-kilodalton ( $\mathrm{kDa}$ ) glycosylated IGFBP-3 fragment contained in the approximately 130 - to $150-\mathrm{kDa}$ ternary complex. Journal of Clinical Endocrinology and Metabolism 78 1119-1127.

Baxter RC \& Martin JL 1986 Radioimmunoassay of growth hormone-dependent insulin-like growth factor binding protein in human plasma. Journal of Clinical Investigation 78 1504-1512.

Binoux M \& Hossenlopp P 1988 Insulin-like growth factor (IGF) and IGF-binding proteins: comparison of human serum and lymph. Journal of Clinical Endocrinology and Metabolism 6 509-514.

Blat C, Villaudy J \& Binoux M 1994 In vivo proteolysis of serum insulin-like growth factor (IGF) binding protein-3 results in increased availability of IGF to target cells. Journal of Clinical Investigation 93 2286-2290.

Blum WF, Ranke MB, Kietzmann K, Gauggel E, Zeisel HJ \& Bierich JR 1990 A specific radioimmunoassay for the growth 
hormone $(\mathrm{GH})$-dependent somatomedin-binding protein: its use for diagnosis of GH deficiency. Journal of Clinical Endocrinology and Metabolism 70 1292-1298.

Cheetham TD, Holly JMP, Baxter RC, Meadows K, Jones J, Taylor AM \& Dunger DB 1998 The effects of recombinant human IGF-I administration on concentrations of acid labile subunit, IGF binding protein-3, IGF-I, IGF-II and proteolysis of IGF binding protein-3 in adolescents with insulin-dependent diabetes mellitus. Journal of Endocrinology 157 81-87.

Conover CA 1992 Potentiation of insulin-like growth factor (IGF) action by IGF-binding protein-3: studies of underlying mechanism. Endocrinology 130 3191-3199.

Cotterill AM, Holly JM, Taylor AM, Davies SC, Coulson VJ, Preece MA, Wass JAH \& Savage MO 1992 The insulin-like growth factor (IGF)-binding proteins and IGF bioactivity in Laron-type dwarfism. Journal of Clinical Endocrinology and Metabolism 74 56-63.

Cotterill AM, Mendel P, Holly JM, Timmins AG, Camacho-Hubner C, Hughes SC, Ross RM, Blum WF \& Langford RM 1996 The differential regulation of the circulating levels of the insulin-like growth factors and their binding proteins (IGFBP) 1, 2 and 3 after elective abdominal surgery. Clinical Endocrinology 44 91-101.

Davenport ML, Clemmons DR, Miles MV, Camacho-Hubner C, D'Ercole AJ \& Underwood LE 1990 Regulation of serum insulin-like growth factor-I (IGF-I) and IGF binding proteins during rat pregnancy. Endocrinology 127 1278-1286.

Davenport ML, Isley WL, Pucilowska JB, Pemberton LB, Lyman B, Underwood LE \& Clemmons DR 1992 Insulin-like growth factor-binding protein-3 proteolysis is induced after elective surgery. Journal of Clinical Endocrinology and Metabolism 75 590-595.

De Mellow JSM \& Baxter RC 1988 Growth hormone-dependent insulin-like growth factor (IGF) binding protein both inhibits and potentiates IGF-I-stimulated DNA synthesis in human skin fibroblasts. Biochemical and Biophysical Research Communications 156 199-204.

Domene H, Krishnamurthi K, Eshet R, Gilad I, Laron Z, Koch I, Stannard B, Cassorla F, Roberts CT Jr \& LeRoith D 1993 Growth hormone $(\mathrm{GH})$ stimulates insulin-like growth factor-I (IGF-I) and IGF-I-binding protein-3, but not GH receptor gene expression in livers of juvenile rats. Endocrinology 133 675-682.

Fernihough JK, Billingham ME, Cwyfan-Hughes S \& Holly JM 1996 Local disruption of the insulin-like growth factor system in the arthritic joint. Arthritis and Rheumatism 39 1556-1565.

Fielder PJ, Thordarson G, Talamantes F \& Rosenfeld RG 1990 Characterization of insulin-like growth factor binding proteins (IGFBPs) during gestation in mice: effects of hypophysectomy and an IGFBP-specific serum protease activity. Endocrinology 127 2270-2280.

Fielder PJ, Guevara-Aguirre J, Rosenbloom AL, Carlsson L, Hintz RL \& Rosenfeld RG 1992 Expression of serum insulin-like growth factors, insulin-like growth factor-binding proteins, and the growth hormone-binding protein in heterozygote relatives of Ecuadorian growth hormone receptor deficient patients. Journal of Clinical Endocrinology and Metabolism 74 743-750.

Fielder PJ, Mortensen DL, Mallet P, Carlsson B, Baxter RC \& Clark RG 1996 Differential long-term effects of insulin-like growth factor-I (IGF-I), growth hormone (GH), and IGF-I plus GH on body growth and IGF binding proteins in hypophysectomized rats. Endocrinology 137 1913-1920.

Frost VJ, Macaulay VM, Wass JAH \& Holly JMP 1993 Proteolytic modification of insulin-like growth factor-binding proteins: comparison of conditioned media from human cell lines, circulating proteases and characterized enzymes. Journal of Endocrinology 138 545-554.

Gargosky SE, Tapanainen P \& Rosenfeld RG 1994 Administration of growth hormone $(\mathrm{GH})$, but not insulin-like growth factor-I (IGF-I) by continuous infusion can induce the formation of the 150-kilodalton IGF-binding protein-3 complex in GH-deficient rats. Endocrinology 134 2267-2276.
Gibson TLB \& Cohen P 1999 Inflammation-related neutrophil proteases, cathepsin $\mathrm{G}$ and elastase, function as insulin-like growth factor binding protein proteases. Growth Hormone and IGF Research $9241-253$.

Giudice LC, Farrell EM, Pham H, Lamson G \& Rosenfeld RG 1990 Insulin-like growth factor binding proteins in maternal serum throughout gestation and in the puerperium: effects of a pregnancy-associated serum protease activity. Journal of Clinical Endocrinology and Metabolism 71 806-816.

Halloran MM, Szekanecz Z, Barquin N, Haines GK \& Koch AE 1996 Cellular adhesion molecules in rat adjuvant arthritis. Arthritis and Rheumatism 39 810-819.

Hossenlopp P, Seurin D, Segovia-Quinson B, Hardouin S \& Binoux M 1986 Analysis of serum insulin-like growth factor binding protein using Western blotting: use of the method for titration of the binding proteins and competitive binding studies. Analytical Biochemistry 154 138-143.

Hossenlopp P, Segovia B, Lassarre C, Roghani M, Bredon M \& Binoux M 1990 Evidence of enzymatic degradation of insulin-like growth factor-binding proteins in the $150 \mathrm{~K}$ complex during pregnancy. Journal of Clinical Endocrinology and Metabolism $\mathbf{7 1}$ $797-805$

Ibáñez de Cáceres I, Villanúa MA, Soto L, Martín AI \& López-Calderón A 2000 IGF and IGF-binding proteins in rats with adjuvant-induced arthritis given recombinant human growth hormone. Journal of Endocrinology 165 537-544.

Koedam JA, Hoogerbrugge CM \& van Buul-Offers SC 1998 Insulin-like growth factor-binding protein-3 protease activity in Snell normal and Pit-1 deficient dwarf mice. Journal of Endocrinology 157 295-303.

Lamson G, Giudice LC \& Rosenfeld RG 1991 A simple assay for the proteolysis of insulin-like growth factor binding protein-3 (IGFBP-3). Journal of Clinical Endocrinology and Metabolism 72 1391-1394.

Langman CB, Ford KK, Pachman LM \& Glorieux F 1990 Vitamin D metabolism in rats with adjuvant-induced arthritis. Journal of Bone and Mineral Research 5 905-913.

Laron Z, Kowadlo-Silbergeld A, Eshet R \& Pertzeland A 1980 Growth hormone resistance. Annals of Clinical Research 12 269-277.

Lassarre C, Duron F \& Binoux M 2001 Use of the ligand immunofunctional assay for human insulin-like growth factor (IGF) binding protein-3 (IGFBP-3) to analyze IGFBP-3 proteolysis and IGF-I bioavailability in healthy adults, GH-deficient and acromegalic patients, and diabetics. Journal of Clinical Endocrinology and Metabolism 86 1942-1952.

Lemmey AB, Glassford J, Flick-Smith HC, Holly JMP \& Pell JM 1997 Differential regulation of tissue insulin-like growth factor-binding protein (IGFBP)-3, IGF-I and IGF type 1 receptor mRNA levels, and serum IGF-I and IGFBP concentrations by growth hormone and IGF-I. Journal of Endocrinology 154 319-328.

Lemmey A, Maddison P, Breslin A, Cassar P, Hasso N, McCann R, Whellams E \& Holly J 2001 Association between insulin-like growth factor status and physical activity levels in rheumatoid arthritis. Journal of Rheumatology 28 29-34.

López-Bote JP, Bernabeu C, Marquet A, Fernández JM \& Larraga V 1988 Adjuvant-induced polyarthritis: synovial cell activation prior to polyarthritis onset. Arthritis and Rheumatism 31 769-775.

López-Calderón A, Soto L \& Martín AI 1999 Chronic inflammation inhibits GH secretion and alters the serum insulin-like growth factor system in rats. Life Sciences 65 2049-2060.

López-Calderón A, Ibáñez de Cáceres I, Soto L, Priego T, Martín AI \& Villanúa MA 2001 The decrease in hepatic IGF-I gene expression in arthritic rats is not associated with modifications in hepatic GH receptor mRNA. European Journal of Endocrinology 144 $1-6$.

Martin JL \& Baxter RC 1992 Insulin-like growth factor binding protein-3: biochemistry and physiology. Growth Regulation 2 88-99. 
van Neck JW, Berghout EM, Vinter-Jensen L, Groffen CA, Cingel V, Dits NF, Drop SL \& Flyvbjerg A 2000 The effect of epidermal growth factor and IGF-I infusion on hepatic and renal expression of the IGF-system in adult female rats. Journal of Endocrinology 165 $115-122$.

Neidel J 2001 Changes in systemic levels of insulin-like growth factors and their binding proteins in patients with rheumatoid arthritis. Clinical and Experimental Rheumatology 19 81-84.

Neidel J, Blum WF, Schaeffer HJ, Schulze M, Schonau E, Lindschau J \& Foll J 1997 Elevated levels of insulin-like growth factor (IGF) binding protein-3 in rheumatoid arthritis synovial fluid inhibit stimulation by IGF-I of articular chondrocyte proteoglycan synthesis. Rheumatology International 17 29-37.

Neidhart M \& Flückiger EW 1992 Hyperprolactinaemia in hypophysectomized or intact male rats and the development of adjuvant arthritis. Immunology 77 449-455.

Olivecrona H, Hilding A, Ekström C, Barle H, Nyberg B, Möller C, Delhanty PJ, Baxter RC, Angelin B, Ekström TJ \& Tally M 1999 Acute and short-term effects of growth hormone on insulin-like growth factors and their binding proteins: serum levels and hepatic messenger ribonucleic acid responses in humans. Journal of Clinical Endocrinology and Metabolism 84 553-560.

Roubenoff R, Freeman LM, Smith DE, Abad LW, Dinarello CA \& Kehayias JJ 1997 Adjuvant arthritis as a model of inflammatory cachexia. Arthritis and Rheumatism 40 534-539.

Rustihauser J, Schmid C, Hauri C, Froesch ER \& Zapf J 1993 Growth hormone, but not insulin-like growth factor I, induces a serum protease activity for insulin-like growth factor binding protein-3 in hypophysectomized rats in vivo. FEBS Letters 334 23-26.

Scharf JG, Ramadori G, Braulke T \& Hartmann H 1996 Synthesis of insulinlike growth factor binding proteins and of the acid-labile subunit in primary cultures of rat hepatocytes, of Kupffer cells, and in cocultures: regulation by insulin, insulinlike growth factor, and growth hormone. Hepatology 23 818-827.

Selgas L, Arce A, Esquifino AI \& Cardinali DP 1997 Twenty-fourhour rhythms of serum ACTH, prolactin, growth hormone, and thyroid-stimulating hormone, and of median-eminence norepinephrine, dopamine, and serotonin, in rats injected with Freund's adjuvant. Chronobiology International 14 253-265.

Skjaerbaek C, Frystyk J, Ørskov H, Kissmeyer-Nielsen P, Jensen MB, Laurberg S, Møller N \& Flyvbjerg A 1998a Differential changes in free and total insulin-like growth factor I after major, elective abdominal surgery: the possible role of insulin-like growth factor-binding protein-3 proteolysis. Journal of Clinical Endocrinology and Metabolism 83 2445-2449.
Skjaerbaek C, Kaal A, Møller J, Vahl N, Weeke J, Ørskov H \& Flyvbjerg A $1998 b$ No effect of growth hormone on serum insulin-like growth factor binding protein-3 proteolysis. Journal of Clinical Endocrinology and Metabolism 83 1206-1210.

Soto L, Martín AI, Millán S, Vara E \& López-Calderón A 1998 Effects of endotoxin lipopolysaccharide administration on the somatotropic axis. Journal of Endocrinology 159 239-246.

Støving RK, Flyvbjerg A, Frystyk J, Fisker S, Hangaard J, Hansen-Nord M \& Hagen C 1999 Low serum levels of free and total insulin-like growth factor I (IGF-I) in patients with anorexia nervosa are not associated with increased IGF-binding protein-3 proteolysis. Journal of Clinical Endocrinology and Metabolism 84 $1346-1350$.

Szekanecz Z, Halloran MM, Volin MV, Woods JM, Strieter RM, Haines GK, Kunkel SL, Burdick MD \& Koch AE 2000 Temporal expression of inflammatory cytokines and chemokines in rat adjuvant-induced arthritis. Arthritis and Rheumatism 43 1266-1277.

Tavera C, Abribat T, Reboul P, Dore S, Brazeau P, Pelletier JP \& Pelletier JM 1996 IGF and IGF-binding protein system in the synovial fluid of osteoarthritic and rheumatoid arthritic patients. Osteoarthritis Cartilage 4 263-274.

Vaccarello MA, Diamond FBJ, Guevara-Aguirre J, Rosenbloom AL, Fielder PJ, Gargosky S, Cohen P, Wilson K \& Rosenfeld RG 1993 Hormonal and metabolic effects and pharmacokinetics of recombinant insulin-like growth factor-I in growth hormone receptor deficiency/Laron syndrome. Journal of Clinical Endocrinology and Metabolism 77 273-280.

Villafuerte BC, Koop BL, Pao CI, Gu L, Birdsong GG \& Philips LS 1994 Coculture of primary rat hepatocytes and nonparenchymal cells permits expression of insulin-like growth factor binding protein-3 in vitro. Endocrinology 134 2044-2050.

Whellams EJ, Maile LA, Fernihough JK, Billingham MEJ \& Holly JMP 2000 Alterations in insulin-like growth factor binding protein-3 proteolysis and complex formation in the arthritic joint. Journal of Endocrinology 165 545-556.

Wooley PH 1991 Animal models of rheumatoid arthritis. Current Opinion in Rheumatology 3 407-420.

Yamada M, Hasegawa T \& Hasegawa Y 1999 Absence of proteolysis of insulin-like growth factor binding protein-3 in serum from patients with growth hormone deficiency. Endocrine Journal 46 717-722.

Received 24 October 2001

Accepted 11 January 2002 